\title{
A COMUNICAÇÃO CORPORAL COMO SABER DOCENTE
}

Djavan Antério ${ }^{1}$

Pierre Normando Gomes-da-Silva ${ }^{2}$

\begin{abstract}
Resumo
Este artigo discute a Comunicação Corporal como um saber docente. Constatando a concepção reduzida do corpo no processo ensino-aprendizagem e a não inclusão dessa temática no rol dos saberes docentes, esta pesquisa elucida as possibilidades de um agir pedagógico mais consciente do próprio corpo na ação educativa. Parte do princípio que o nível de consciência do professor acontece quando ele compreende que seus gestos, roupas e ocupações nos espaços da sala de aula, são tão eloquentes quanto as informações transmitidas sobre determinado assunto. Defende-se, portanto, que a linguagem corporal consciente pode se constituir num saber docente útil para a prática educativa do professor.
\end{abstract}

Palavras-chave: Educação; Saber; Comunicação; Corpo

\section{INTRODUÇÃO}

O estudo proposto toma o "corpo" como base de discussão, levando em consideração suas diversificadas formas e possibilidades comunicativas. Para isso ampliamos a compreensão do corpo para além de toda sua complexa estruturação física, mecânica e

\footnotetext{
${ }^{1}$ Mestre e Doutorando e em Educação pelo Centro de Educação da UFPB / Vinculação institucional: Professor do Departamento de Pedagogia (modalidade à distância) da mesma instituição; Pesquisador membro do Grupo de Estudos e Pesquisas em Corporeidade, Cultura e Educação (GEPEC) - CNPq do Centro de Ciências da Saúde - Campus I da UFPB Endereço: Rua Cassimiro de Abreu, n 300 , apt ${ }^{\circ} 303$ B, Brisamar, João Pessoa-PB,Brasil. CEP: 58033-330. / Telefone (celular): (83) 88550281 / Endereço eletrônico: djavananterio@ gmail.com

${ }^{2}$ Doutor em Educação pela UFRN, 2003 / Vinculação institucional: Professor Associado do Departamento de Educação Física/CCS/UFPB; Líder do Grupo de Estudos e Pesquisas em Corporeidade, Cultura e Educação (GEPEC) - CNPq do Centro de Ciências da Saúde - Campus I da UFPB. Endereço: Rua Pres. Roosevelt, $\mathrm{n}^{\circ} 128$, apt $^{\circ}$ 101, Expedicionários, João Pessoa-PB, Brasil., CEP: 58040-730. / Telefone (celular): (83) 8772.4898 / Endereço eletrônico: pierrenormandogomesdasilva@gmail.com
} 
ANTÉRIO, D.; SILVA, P. N. G.

motora, e o abordamos incluindo a intersubjetividade psíquica, social e cultural decorrente das interações estabelecidas. Porque o tomamos na perspectiva do "corpo comunicativo", ou seja, da espacialidade existencial corpórea constituída nas interações com o mundo e consigo mesmo, daí, a corporeidade (GOMES-DA-SILVA, 2011).

Ancorando-nos em autores que exploram e abordam o corpo de maneira comunicativa, apresentamos pontos a serem debatidos e refletidos na intenção de fomentar o valor desta área do conhecimento, sobretudo para Educação (ARGYLE, 1988; CORRAZE, 1982; FREIRE, 1999; GLUSBERG, 2003; KNAPP; HALL, 1999; MEDINA, 2002; MERLEAU-PONTY, 1999; PICARD, 1986; RECTO; TRINTA, 1985). Cada qual à sua maneira, os autores oferecem visões que abarcam uma concepção de "corpo sem órgãos" (DELEUZE; GATARRI, 1995), ao dialogar a presença e a ação do sujeito no contexto no qual se insere como uma produção de sentido. É possível evidenciar o ato de movimentar-se como diálogo com o outro e com o meio, numa interatividade entre corpos e contextos, observando-o pelas ações gestuais, posturais e espaciais.

Propomos uma ampliação da concepção de corpo, compreendendo-o como corporeidade, e mais, ao focarmos a interação dos corpos entre si, num contexto socioeducativo. Isso pelo fato de abordarmos a relação existencial entre educador e educando, compartilhando e se relacionando num mesmo espaço escolar habitado por certo padrão de funcionalidade. Partimos do princípio de que no processo formativo, esta relação deve ser levada em consideração por ser e vir dela a intersubjetividade das contingências do saber e do compartilhar, do fazer e do experimentar, do criar e do inventar.

Esta perspectiva não é comum no contexto acadêmico, em termos de produção de conhecimento, nem no ambiente escolar, no que se refere a tomada de consciência dos professores sobre a comunicação existente no processo ensino-aprendizagem. Nossa pretensão contempla um modo diferente de aprender e de ensinar, enraizado nas percepções e interações ambientais. Diríamos, uma educação vista a partir da "zona de corporeidade" (GOMES-DA-SILVA, 2011), com uma ambiência comunicativa surgida da interação entre os corpos humanos e não humanos no espaço escolar. Os corpos existencialmente vividos em interação com o entorno, consigo e com o outro, apresentam-se como possibilidade comunicativa e nos oferecem condições para abrir debates tanto físico-motores quanto conceituais. Obviamente, é necessário uma abertura de pensamento, um aguçamento no olhar 
para adentrarmos nessa zona de corporeidade existente em todo processo de comunicação, seja ele escolar ou familiar.

Estudos anteriores como os de Galvão (2004) e Gaia (2006), afloram pertinentes discussões acerca do corpo e suas implicações no contexto educacional. Num esforço de síntese, os autores recaem na tendência de abordar o corpo e educação, contemplando de modo fragmentário alguns aspectos, tais como: gênero, sexualidade, disciplinarização, higienização e controle. Essas investigações não contemplam o "ser corpo", como um todo existencial, em contextos curriculares, tal como pode ser visto em Cozzi (2004), Farah (2011) e Fernandes (2004). Paralelo a estes, temos a tendência investigativa da "consciência corporal" na formação de professores e suas representações e relações com a prática pedagógica, o que pode ser visto nos trabalhos de Angheben (2005), Bacri (2005) e Pederiva (2005). Nossa perspectiva inclui estas percepções e formulações apresentadas anteriormente, a partir da consciência da Zona de Corporeidade ou da Comunicação Corporal (CC) como um saber docente.

Como fonte de elementos para discussão e análise, apropriamo-nos de resultados concretos advindos de dois anos de pesquisa em nível de mestrado (stricto sensu), investigando as repercussões pedagógicas resultantes da intervenção na CC do educador físico atuante no âmbito escolar. Tais resultados podem ser aprofundados em publicações anteriores (ANTÉRIO; GOMES-DA-SILVA, 2011; 2012). Ademais, buscando uma reflexão crítica do processo dialético entre teoria e prática, emergimos com pensamentos dos autores supracitados no intuito de configurar uma rede de interação intelectual acerca da prática docente. Dessa forma, o estudo se apresenta com cunho qualitativo, recorrendo, de forma geral, à análise bibliográfica em conexão com a prática pedagógica.

Outro aspecto importante a ser aclarado é sobre quais critérios avaliamos a ação comunicativa. Referenciando os resultados da pesquisa realizada com educadores físicos (ANTÉRIO; GOMES-DA-SILVA, 2013), valemo-nos da perspectiva do corpo como percepção e comunicação. Identificamos alguns problemas relacionados à comunicação enfrentados por estes, sobretudo no que confere suas práticas docentes: (a) pouca atitude corporal ao comunicar-se; (b) dificuldade em adaptar-se ao meio em que está inserido; e (c) timidez ao expressar-se. A partir daí, organizando e sistematizando ações de intervenção, nos conduzimos pela seguinte questão-problema: Como a comunicação corporal pode repercutir pedagogicamente na capacidade interventiva do educador? 
ANTÉRIO, D; SILVA, P. N. G.

Entretanto, ao aprofundarmos no contexto educacional como um todo, refletimos aqui baseados no processo de interação social que se dá neste contexto, quer seja entre educador e educando, quer seja entre os educandos. Caminhamos à luz do que nos traz Vygotsky (1989), referenciando a linguagem - ou "língua"- no processo de inter-relação com o outro e com o meio, para a formação do sujeito crítico e reflexivo. A linguagem surge como mediação e fomento de nossas potencialidades intelectuais, psíquicas, motoras. Logo, a partir do que fundamenta Vygostky (1989), o sujeito se desenvolve a partir da interação dos elementos internos, vindo dele mesmo, e elementos externos, resultantes do próprio ambiente. Por conseguinte, tal processo de interação nos ajuda a nos posicionarmos frente às circunstâncias, ganhando diretividade, foco na ação, bem como subjetividade ao significarmos as relações para com o outro.

\section{DO CORPO À ZONA DE CORPOREIDADE: CONSIDERAÇÕES PRELIMINARES}

O corpo como tema investigativo vem sendo desenvolvido ao longo destas últimas décadas, desde Marcel Mauss (1934), nas investigações antropológicas das "técnicas corporais" para além das tradicionais abordagens fisiológicas ou biomecânicas, sobretudo no campo da arte. Estudos atuais vêm dando a devida consideração à diversidade da comunicação corporal, submetido a processos de reflexão e introspecção, valorizando o íntimo da consciência (corporal) que, por tabela, acaba por considerar aspectos fundamentais como gestualidade, postura e ocupação espacial (ARGYLE, 1988; CORRAZE, 1982).

Tal como fundamenta Miller (2013), partimos da premissa que a experiência corporal é o objetivo primeiro das proposições interativas, ainda mais quando ocorridas em âmbito educacional. Logo, abordagens e propostas pedagógicas são aclaradas e discutidas a partir desta perspectiva, onde o corpo em comunicação com o ambiente é tido como um elemento importante no processo de formação educacional.

Vale ressaltar nossa contraposição a toda e qualquer estratégia de domesticar o corpo, retirando-lhe ou diminuindo a comunicação e interação com o entorno e isolando-o em espaços reduzidos. Nos contrapomos às disciplinas educacionais que visam a obediência por meio da formação do "corpo dócil", do corpo submisso, exercitado, adestrado e fabricado pela disciplina. Tratamos de um "corpo presente, na escuta de si, que traça um caminho de dentro 
para fora, em sintonia com o de fora para dentro e com o de dentro para dentro, criando, assim, uma ampla rede de percepções” (MILLER, 2013, p. 100).

Numa outra lógica educativa ressaltamos nosso entendimento acerca do corpo comunicativo, a qual abrangeu nossas reflexões. Norteamo-nos pela dimensão conceitual que caracteriza o homem e seu corpo num só constituinte. Isto é, entendemos o corpo comunicativo como unidade existencial, que nos dá visibilidade e acessibilidade ao mundo no qual estamos inseridos. Tal como aponta Farah (2010), está contida nessa concepção, a ideia de que, em toda e qualquer ação que realizamos, é possível verificar três dimensões explícitas: biológica; psicológica; e sócio-histórica. Evidenciamos nesta pesquisa a ação comunicativa corporal do educador a partir da perspectiva do corpo como percepção e expressão interrelacional do sujeito no mundo. Isto significa debruçarmos o olhar sobre a comunicação (corporal) do educador consigo mesmo, com seus alunos e com o seu entorno escolar.

Valendo-nos da possibilidade de conscientização corporal, onde o sujeito sente, pensa e age com e por meio do corpo, vislumbramos novas formas de expressão e comunicação no contexto educacional. O objetivo é levar os partícipes da ação (educador e educando) a uma descoberta e reconhecimento de si, vislumbrando assim as reais possibilidades colaborativas no constante processo de aprendizagem (FREIRE, 1999). Por isso são considerados partícipes educacionais, que estão conscientes dessa ação comunicativa no ato de mover-se. E algo que vem a colaborar para esta visão, é a possibilidade vivencial de práticas corporais de conscientização do corpo, estando este em constante processo de percepção e investigação da circunstância para assim poder agir nela.

A partir do conceito de "corpo dócil", Foucault (1987) descreve as estratégias ou tecnologias biopolíticas de submissão do corpo a coerções, mantendo-o sob um olhar disciplinador. "Constata-se que um corpo dominado é um corpo dicotômico submetido ao comando mental, impedindo sua liberdade para responder às suas próprias necessidades, como um instrumento apto a corresponder às nossas exigências sob controle da mente" (FOUCAULT, 1987, p. 83). É justamente a essas tecnologias que nos contrapomos, uma vez que defendemos o corpo comunicativo como evidência existencial, construída e desenvolvida gradativamente, conectada à conjuntura tanto da tradição cultural, com seus costumes e hábitos, quanto às possibilidades criativas de construções de outros arranjos históricos e afetivo-cognitivos. São esses modos de interação e comunicação com o entorno, que explicitaremos os desenhos intersubjetivos, ou a zona de corporeidade (GOMES-DA-SILVA, 
ANTÉRIO, D; SILVA, P. N. G.

2011), por meio da tendência dos gestos, explícitas nas ações e inações, posturas e ocupações no espaço.

Deste modo, a sequência dos gestos provoca uma situação de movimento que denominamos de zona de corporeidade. Significa uma ambiência comunicativa e constitutiva do ser que se move. Mais explicitamente, estamos defendendo que o corpo comunicativo não é compreendido nele só, mas em seu contexto, na situação de movimento a que está inserido. E que esta situação não se reduz a uma rede de comunicação entre muitos corpos (emissores e receptores), por meio de canais e códigos, mas sim configurado numa zona, onde todos os elementos estão em comunicação ao mesmo tempo, não só humanos, mas também os objetos, espaços, clima, ambiente.

Na comunicação há sempre um contexto, segundo Jakobson (1999), de modo que emissores e destinatários estão entrelaçados, intercambiados, já que tudo está em comunicação com tudo. Tudo está em comunicação ao mesmo tempo, num contínuo de fluxos de informação. Há possibilidade comunicativa em que emissor é receptor no mesmo instante em que é mensagem, uma vez que toda a área está em comunicação. Ou seja, defendemos essa situação de movimento, esse ambiente comunicativo, como constituinte do próprio sujeito, portanto é ontológica. Não só amplifica os aparelhos perceptivos, capta, interpreta, recria e comunica mensagens, mas também modula afetos, que coordenam as ações no mundo.

\section{A COMUNICAÇÃO CORPORAL}

Partindo do princípio de que o corpo comunicativo oferece informações importantes a serem consideradas, sobretudo no que se refere a sua relação com outros sujeitos da educação, focamos a comunicação revelada nas ações corporais. Assim, priorizamos os significados dos movimentos, da gestualidade, seja ela pragmática ou intuitiva, ao estabelecer as interações com o outro. O corpo comunicativo, portanto, deve ser compreendido para além das funções fisiológicas, motoras, considerando suas diversificadas dimensões interativas, individuais e coletivas, emocionais e sociais, ambientais e circunstanciais. A comunicação, muitas vezes, é silenciosa, invisível, não verbalizada. Difunde-se pelos gestos, pelo movimento, pelo olhar, pelo jeito de ser e estar de cada um. 
Ao focarmos a comunicação estabelecida corporalmente, tratamos de maneira mais específica da linguagem não-verbal. Ancorando-nos em Argyle (1988) e Knapp e Hall (1999), é possível defini-la como uma ação que envolve diferentes manifestações de comportamento não expressas por palavras e pela escrita, tais como os gestos, expressões faciais, posturas, relação de distância e aproximações entre sujeitos e, ainda, pela organização dos objetos no espaço. De forma geral, pode ser observada na pintura, literatura, escultura, e em outras formas de expressão humana, como a dança e o teatro. Porém, apesar de estar bastante presente em nosso cotidiano, muitas vezes, não temos a consciência de sua ocorrência, muito menos como, de fato, acontece. Para Davis (1979), compreendendo a comunicação humana como uma área de investigação complexa, define a linguagem não-verbal como forma não discursiva, transmissível por três suportes: o corpo; os objetos associados ao corpo; e os produtos da habilidade humana.

Sustentando a subjetividade corporal, ao abordar o sistema comunicativo não-verbal, Argyle (1988) distingue os seguintes canais de comunicação: expressão facial; olhar; gestos e movimentos posturais; contato corporal; comportamento espacial; roupas, aspecto físico e outros aspectos da aparência. Esses canais fazem parte de uma categorização denominada por ele de Diferentes Sinais Corporais. Os gestos e os movimentos, de acordo com o autor, compõem os inúmeros canais de comunicação que o ser humano utiliza para expressar-se, comunicar-se, enfim, transmitir informações que considera necessárias para se fazer entender em um dado momento. Já com Knapp e Hall (1999), temos um esquema de classificação bem mais detalhado da conduta não-verbal, sendo ela dividida em sete áreas de acordo com a literatura ou com as investigações científicas: a) movimento corporal ou cinésica (emblemas, ilustradores, expressões de afeto, reguladores e adaptadores); b) características físicas; c) comportamentos táteis; d) paralinguagem, referindo-se às qualidades vocais e vocalização); e) proxêmica; f) artefatos; e g) o meio ambiente.

Como a intenção é discutirmos a CC no contexto da educação, elucidamos a área da paralinguagem no intuito de demonstrar que o ato de ensinar é linguagem verbal e não-verbal continuamente, inseparável. Atrelando-se ao verbal, o não-verbal se dissemina quase que naturalmente. Peguemos o exemplo do educador que usa da entonação vocal para impor respeito, ou mesmo uma atitude mais ríspida, algo gesticular, exigindo que o educando saia da sala por não estar colaborando com o andamento da aula. O fato é que dificilmente nos comunicamos sem que o gesto corporal não se atrele a linguagem verbal. Contudo, nos cursos 
de formação de professor, por exemplo, a noção de corpo comunicativo, no processo de ensino-aprendizagem é ainda muito vaga, apresentando-se como uma simples matéria, um envelopamento da mente, algo distante do ser pensante. Não pensamos o corpo comunicativo, agimos pelo simples fato de termos de fazê-lo.

Indo de encontro a este entendimento, buscamos alertar para compreensão da comunicação entre os envolvidos no contexto educacional, otimizando o processo formativo, potencializando o ato de ensinar e aprender. Mais que isso, contemplando o simples fato de relacionar-se com o outro em prol da socialização, da construção coletiva do conhecimento e do saber. Destacamos assim a compreensão da CC como ferramenta de equivalência ao poder da palavra, criando ligações e conexões com e para o outro. Isso pelo fato de sabermos que o comportamento não-verbal pode perfeitamente repetir, contradizer, substituir, complementar, acentuar ou regular o comportamento verbal (KNAPP; HALL, 1999).

Daí evidenciarmos a necessidade de os profissionais de educação, especificamente os que atuam no âmbito escolar, em considerar a comunicação do corpo, a fim de serem mais eficientes no desenvolvimento de suas atividades. Ainda são escassos os trabalhos que estudam a relação corpo-movimento-comunicação, sob uma intenção de ativar a percepção dos sinais não-verbais em busca do melhoramento da ação interventiva do professor.

Nossa abordagem da CC não se restringe aos canais comunicativos, se bem que só esse aspecto já é por demais abrangente. Mas também compreendemos a comunicação como um diálogo entre o homem e o mundo (WEIL; TOMPAKOW, 1986). O movimentar-se, segundo Gomes-da-Silva (2011), é uma forma da existência, em que se têm os próprios valores e onde o homem realiza sua historicidade. Ressaltamos os movimentos humanos em sala de aula não de forma reducionista à funcionalidade das tarefas docentes, mas constituídos como mensagem, transmissores de intenção. A pesquisa de Costa et. al. (2012) demonstraram, por exemplo, que o andar do professor revela sua atitude pedagógica. Neste estudo, os autores identificaram que para cada ato específico, conduzir a turma, disciplinar alunos e organizar a aula, a qualidade do andar do professor se modifica, altera em si mesmo.

Realçamos a intencionalidade dos atos corporais do educador em sala de aula, mesmo que sejam inconscientes para ele. A busca é para que os educadores tomem consciência do sentido comunicativo dos seus movimentos em sala de aula. Ao contrário da teoria e prática da educação hegemônica, que trata os movimentos como destrezas ou habilidades motoras padronizadas, concebemos o movimento pela linguagem. Sendo assim, posturas, posições, 
deslocamentos, feições, roupas, objetos "não são tomados como fragmentos inocentes da comunicação, mas constituintes de configurações múltiplas e cambiantes de uma teia de significados. Os movimentos e os não-movimentos são identificados como dizíveis" (GOMES-DA-SILVA, 2011, p. 335).

\section{O SABER DOCENTE}

Partindo da tese de que a CC é um saber docente, faz-se necessário apresentar nossa compreensão acerca daquilo que entendemos por saber docente. A intenção é elucidar o que é e como percebemos a ação docente imbuída do saber comunicar. Evidenciaremos, portanto, aspectos que dialogam com o que já é consolidado enquanto saber, porém com certa diferenciação conceitual, trazendo à tona uma concepção que se refere ao "sujeito-corpo", que, por si só, ao relacionar-se com o outro e até mesmo com o meio, estabelece situações comunicativas, informando e sendo informado sobre algo.

Ao longo de sua trajetória profissional, o professor se apropria de saberes que correspondem aos discursos e metodologias dos quais a instituição escolar categoriza e apresenta como modelos culturais. Este professor, de acordo com Rodrigues e Villalba (2008), se depara com inúmeros desafios, os quais requerem uma postura crítica que pressupõe capacitação constante, estudo continuado, curiosidade e interesse em estar atualizado, pois, ensinar e aprender, ao mesmo tempo, como mestre e aprendiz, são requisitos fundamentais aos que se dedicam à profissão docente.

Compreendemos que o saber docente está diretamente ligado a uma relação pedagógica centrada nas necessidades e interesses do processo ensino-aprendizagem. Nesse contexto, a especificidade deste saber ultrapassa a formação acadêmica, abarcando a prática cotidiana e a experiência vivida do professor. Pode-se dizer que é um saber heterogêneo e plural, adquirido ao longo da vida pessoal e profissional (RODRIGUES; VILLALBA, 2008).

Em decorrência desta perspectiva, a função docente deixa de ser omissa e inerte e passa a focar-se na preparação dos sujeitos para a vida, equipando-os em consonância com o real contexto que os entorna, considerando, em igual medida, os aspectos humanos, históricoculturais, e os aspectos naturais, ecológicos. Sendo assim, o docente requer saberes capazes de serem replicados, difundidos e retroalimentados na relação com seus alunos, contexto e cultura escolar e comunidade científica. 
À luz de Tardif (2006), consideramos que o saber profissional encerra também aspectos psicossociológicos, pois exige do professor um conhecimento sobre si mesmo e um reconhecimento por parte dos outros. O saber do professor é um saber experiencial, pois é prático e complexo. Procurar compreender a racionalidade do fazer pedagógico na sala de aula significa buscar desvelar os saberes de que lança mão para tomar suas decisões. Investigar os saberes, portanto, significa explorar o universo epistemológico que fundamenta o agir pedagógico do professor. A partir deste pensamento, sustentamos a prerrogativa de que, quanto menos utilizável no trabalho é um saber, menos valor profissional parece ter. Isso implica entender que é o agir do professor, a fonte de todos os saberes, sejam os advindos da formação, que se destinavam a melhorar a intervenção profissional futura; sejam os adquiridos já com as experiências do cotidiano escolar. Nesse sentido, o autor identifica e define os diferentes saberes presentes na prática docente, bem como as relações estabelecidas entre eles e os professores. Caracteriza o saber docente como um saber plural formado pelo amálgama mais ou menos coerente de diversos e específicos saberes, oriundos de várias instâncias.

Ainda com Tardif (2006) temos que os saberes docentes dividem-se em: (a) Saberes da formação profissional, que são um conjunto de saberes transmitidos pelas instituições de formação de professores; (b) Saberes disciplinares, correspondendo aos diversos campos do conhecimento, aos saberes de que dispõe a nossa sociedade, tais como se encontram hoje, integrados nas universidades, sob forma de disciplinas, no interior de faculdades e cursos distintos; (c) Saberes curriculares, que correspondem aos discursos, objetos, conteúdos e métodos a partir dos quais a instituição escolar categoriza e apresenta os saberes sociais por ela definidos e selecionados como modelos da cultura erudita e de formação para esta mesma cultura; e (d) Saberes experienciais ou práticos, correspondendo aos saberes baseados no trabalho cotidiano e no conhecimento de seu meio, brotando da experiência individual e coletiva de saber fazer e saber ser.

Sendo assim, podemos classificar o saber docente como complexo e heterogêneo, e que, a partir desta heterogeneidade, implica um processo de aprendizagem e de formação, sendo que, quanto mais desenvolvido, formalizado e sistematizado é um saber, mais longo e complexo se torna o processo de aprendizagem. De modo que defendemos que a CC consciente por parte do professor, pode tornar-se um saber da experiência, por tratar-se de um "saber-ser e um saber-fazer" pessoal e profissional, validado pelo trabalho cotidiano, 
conforme Rodrigues e Villalba (2008). Desta forma, compreendemos ser possível tornar a CC como um conhecimento sistematizado, em seus arcabouços teórico-metodológicos, podendo assim estar presente também nos saberes de formação profissional, proposto por Tardif (2006).

\section{A COMUNICAÇÃO CORPORAL E A AÇÃO DOCENTE}

A comunicação vai muito além do saber falar, saber escrever, enfim, do saber verbalizar. Ao tratarmos de comunicação, pensamos em interação, sejam elas humana ou ambiental, portanto a compreendemos como um fenômeno muito mais complexo e, ao mesmo tempo, muito mais fundamental em nossas vidas. Na perspectiva da semiótica russa, segundo Machado e Romanini (2010, p. 91), comunicação se constitui em processo de interações sociais ou biológicas, visto que "a luta pela informação define o sentido da vida". Comunicação "é a rede de relações que emerge da percepção estética (espaço-temporal), funcionando como uma interface entre a espécie cognoscente e o fluxo de informação que a une ao mundo". Nesse diagrama ontológico proposto por Machado e Romanini (2010), fica delineado uma visão sistêmica, baseada na continuidade dos processos de informação, ultrapassando aquela compreensão dicotômica entre interno-externo, social-biológico, emissor-receptor, sujeito-objeto. Com o fim de tornar visual o diagrama proposto pelos semioticista Machado e Romanini, o delineamos abaixo: 
ANTÉRIO, D.; SILVA, P. N. G.

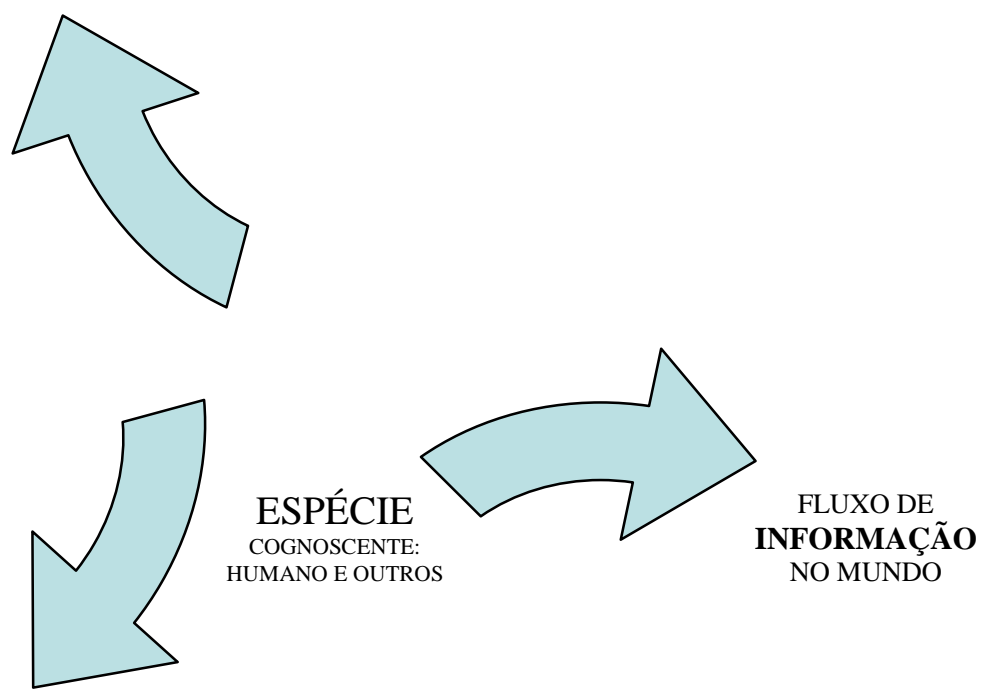

PERCEPÇÃO

ESPAÇO -

TEMPORAL

Figura 1 - Diagrama ontológico da comunicação Adaptação de Machado e Romanini, 2010

Baseamo-nos na perspectiva trazida por Corraze (1982), que afirma ser a comunicação não-verbal um meio, dentre outros, de transmitir informação, não se valendo de linguagem escrita, falada ou seus derivados não-sonoros (linguagem dos surdos-mudos, por exemplo). De acordo com o autor, para o ser humano, as comunicações não-verbais se processam através de três suportes: (i) No corpo, por meio de suas qualidades físicas, fisiológicas e movimentos; (ii) No homem, por meio dos objetos associados ao corpo como os adornos, as roupas, ou mesmo as mutilações (marcas, cicatrizes, tatuagens); e (iii) Na distribuição dos indivíduos no espaço, ocupação do espaço físico e proximidade entre as pessoas no mesmo "espaço territorial". Por conseguinte, considerando essas dimensões comunicativas e suas implicações para a ação docente, entendemos os fatores como atitude, experiência e conhecimento conceitual da área de comunicação não-verbal, como elementos importantes para melhorar a eficiência e a competência daqueles profissionais que atuam, especificamente com movimento em suas interações com outros indivíduos. 
Estendendo a compreensão abordada neste estudo, abrimos espaço para discutir a conduta reflexiva referente a formação profissional do educador. Sobre isso, Vogt e Morosini (2012) reafirmam que a formação de professores, além do processo inicial da sua qualificação profissional, é preciso o entendimento da necessidade de continuidade. O espaço escolar, na verdade, revela-se como o locus adequado para a formação continuada efetivar-se, produzindo mudanças reais na cultura escolar. Por este espaço constituir-se num emaranhado de saberes (curricular e de experiência) e intersubjetividades, tais como o prazer de aprender, a tensão dos conflitos, os medos nos enfrentamentos, a criatividade e a ludicidade na prática educativa. Para isso, sugerimos a estrutura de formação continuada, denominada de Metodologia Colaborativa, na perspectiva que tem sido desenvolvida junto ao Laboratório de Estudos e Pesquisa em Corporeidade, Cultura e Educação (LEPEC/UFPB).

Nessa perspectiva, torna-se fundamental a consciência de que a escola é o espaço privilegiado para se estabelecer a formação continuada por meio de diálogos abertos, teoria e prática, potencialidade e dificuldades, objetividade e subjetividades, universidade e escola que aparecem no decorrer do processo de ensino. Significa abarcar as articulações entre as trocas de experiências e as construções de novas aprendizagens, por meio de trabalhos em equipe, observações, registros e reflexões contínuas e sistematizadas.

Isso por entender que o processo prático-reflexivo na formação continuada de professores é fundante na melhoria da qualidade de ensino, ampliando assim, o debate nesse campo de intervenção com novas contribuições e alternativas de análise. Vieira (2009) apresenta a questão da formação do professor como sendo um assunto que está presente junto às demais preocupações educacionais e que necessita de constantes reflexões para implementar ações concretas.

\begin{abstract}
Uma formação inicial de qualidade é compatível com a diversidade de formas de formação, em oposição à uniformidade da formação de professores. Se a formação não preparar o professor para se inserir nas escolas que existem, com os seus alunos e as suas culturas profissionais, corre o sério risco de formar inadaptados, professores que, ao assumirem funções, se sentem completamente deslocados e inaptos para desempenhar o seu papel. Muitos deles podem mesmo abandonar o ensino. Se a formação não prepara os novos docentes para a mudança educativa e social, assume-se como mais uma força conservadora e, no fundo, complacente com os problemas existentes. (VIEIRA, 2009, p. 137).
\end{abstract}

Corroborando com as ideias de Vieira (2009) e Costa et al. (2011), defendemos que, se o objetivo é formar um professor de acordo com determinados saberes de interação com o 
meio, é preciso considerar os variados contextos institucionais, locais de prática e cultura disciplinar, atrelando de maneira consciente às suas possíveis apropriadas comunicações. Então, múltiplas são as vias de organizar esse percurso, no sentido de atingir os objetivos pretendidos. Assim, estas vias organizativas da comunicação também estarão atreladas ao ensino, ao projeto de formação continuada da instituição, dos recursos e fatores sóciohistóricos condicionantes.

Contudo, para tornarmos o corpo comunicativo em suas possibilidades na educação é preciso começarmos perguntando: "É possível ministrar aula sem corpo?” Muitos responderiam que "Sim", tendo em vista as tecnologias da informação. Apesar de não ser esta a questão que estamos nos referindo, mas quantos professores se reconhecem em suas ações em sala de aula? Qual o nível de consciência das ações docentes dos professores no que se refere aos seus gestos, roupas e ocupações nos espaços da sala de aula, que são tão eloquentes quanto as informações transmitidas sobre determinado assunto?

Tendo consciência de seus potenciais corporais, o professor se comunica, se expressa e, consequentemente, educa de forma mais efetiva. Todavia, é fundamental que avancemos para além do aspecto da instrumentalidade da educação e do próprio corpo. O desafio está em superarmos esse aspecto instrumental que, caracteriza boa parte das abordagens sobre o corpo na educação, notadamente as que guardam relações muito estreitas com a cultura difundida pelos métodos ginásticos ou pelo movimento de esportivização na educação física. Embora possamos nos referir a experiências significativas nesse campo, há muitos desafios a serem superados, para vivenciarmos a compreensão da corporeidade a qual nos atrelamos como princípio epistemológico capaz de ressignificar nossas concepções cognitivas, sociais e educativas.

Ligarmo-nos ao nosso corpo além do aspecto natural da vida é tornar mais perceptível nossas transformações, nossas mudanças, nossas modificações corporais. Notarmos que nosso corpo, com o tempo, não é mais o mesmo, é fato inegável. Porém, estabelecer com ele uma confidente relação de adaptação significativa é respeitar suas limitações e confiar em sua potencialidade relacional. Compreender os fatores inerentes ao processo biológico e, ao mesmo tempo, exprimir-se em suas interações sociais e intenções afetivas, significa consciência de suas ações no mundo.

Aclaramos a relevância em se considerar a CC no processo de ação educativa do sujeito em interação com seu entorno. O corpo comunicativo, quando trabalhado 
adequadamente, pode se mostrar surpreendentemente contribuinte para a ação docente eficaz. Logo, considerar a CC como elemento fundamental para tal acontecimento é revelar ao sujeito sua potencialidade comunicativa não-verbal, em suas efetivas implicações.

Apresentamos um cenário possível de modificações, no qual o professor pode e deve ser o provocador da mudança. Esse cenário inicia pelo processo reflexivo acerca das suas comunicações corporais implicadas no ensinar e aprender. Um processo construído nas relações e interações de uns para com os outros sujeitos da educação, bem como em relação ao entorno, espaço físico, disposição dos móveis, cores e decorações.

Sob o prisma da CC, o ato de movimentar-se toma maiores proporções do que aquelas convencionais do nosso cotidiano. Isto significa irmos além do deslocamento, da postura mais confortável, do mover-se por alguma necessidade. Promovemos a compreensão dos significados do vocabulário corporal, para assim, poder ampliá-los e compartilhá-los. Tratando-se especificamente da esfera educacional, apoiamo-nos no pensamento de Gomesda-Silva (2011), que afirma ser a linguagem corporal sistematizada e ensinada em prol de uma melhor interação entre educador e educando. Para tornar possível que eles façam novos arranjos nos repertórios afetivos e motores e nas representações sociais que possuem.

$\mathrm{Na}$ intenção de aflorar o aspecto educacional da CC, apresentamos algumas importantes questões que fomentam as perspectivas abordadas sobre um viés propriamente pedagógico. Para isso, recorreremos aos pensadores da área que suscitam a questão do saber docente como prerrogativa qualitativa para uma melhor educação. Dentre eles: Gadotti (1998); Sacristán (2005); Tardif (2002); Morin (1997) e Freire (1999). Vale salientar que a "costura" entre os pensamentos emergidos se faz condizente com a pretensão de embasar a questão central do estudo apresentado, o da CC como um saber docente. Por isso, apesar de haver alguns distanciamentos teóricos entre os autores, o que nos interessa é fazer valer os princípios que constituem uma perspectiva educacional, no que tange a prática educativa e suas diversificadas aplicações.

Recorremos à CC creditando a ela a possibilidade de uma mudança, uma efetiva transformação no ato de educar. Partindo de Gadotti (1998), aliamos ao papel social de professores e professoras, a esperança em um futuro melhor para a educação brasileira. Segundo o autor, compete ao "novo educador refazer a educação, reinventá-la" (p. 90). Isso implica na criação de alternativas pedagógicas que favoreçam o aparecimento de um novo tipo de profissional. Sob esta perspectiva, em nossa pesquisa, buscamos o êxito focando na 
ação do professor. Oferecemos elementos que pudessem compor um acervo pedagógico voltado para a melhoria qualitativa do seu processo de intervenção docente.

Com Sacristán (2005), temos a afirmativa de que os sujeitos da educação são constituídos nos diversos cenários existenciais e não apenas no escolar. O autor fundamenta que a marca cultural é prévia à ação, diferenciando a ação da prática. A primeira seria pertencente aos seus agentes, já a segunda pertenceria ao âmbito do social. A consolidação da prática como cultura supõe a causalidade, a liberdade, a decisão livre, e, mesmo assim, há a necessidade da tradição acumulada, entendida como conteúdo e método da ação. Tal como fundamenta Sacristán, pensamos no desafio da pedagogia contemporânea em incorporar, na formação docente, o que já há de acumulado sobre a CC em áreas afins da educação, tal como as Artes e seus segmentos artísticos (teatro, dança, música).

Em relação ao saber docente propriamente dito, espelhamo-nos em Tardif (2002), que defende o saber não reduzido, exclusivo, mas situado no saber do professor e em sua interface entre o individual e o social, entre o ator e o sistema, a fim de captar a sua natureza social e individual como um todo. Deste modo, faz-se também necessário compreender o saber do professor como saberes que têm como objeto de trabalho seres humanos e advêm de várias instâncias (família, escola, cultura). Isso significa respeitar e considerar a pluralidade e a heterogenia inerente ao percurso da vida. Essa concepção da amplitude de saberes que forma o saber do professor, de acordo com Tardif (2002), é fundamental para entendermos a atuação de cada um no processo de trabalho coletivo desenvolvido pela escola.

Guiados por esta concepção, percebemos que o professor insere-se, por meio de sua individualidade e peculiaridade, na construção do processo pedagógico como um todo. Isso garante a diversidade de olhares contribuindo para a ampliação das possibilidades e construção de outros novos saberes. Por isso a importância e a essencialidade de se levar em consideração o conhecimento do trabalho dos professores, seus saberes cotidianos. Tal postura rompe com o tradicionalismo que sustenta a ideia de que professores nada mais são do que transmissores de saberes produzidos por outros grupos.

Por conseguinte, a escola torna-se lugar propício à formação, inovação, pesquisa e reflexão. Para Tardif (2002), o saber docente é um saber plural, oriundo tanto da formação profissional como dos saberes disciplinares, que correspondem aos diversos campos do conhecimento e emergem da tradição cultural; dos saberes curriculares; e também das próprias experiências do trabalho cotidiano. Corroboramos, portanto, com a premissa de que o 
professor deve ter a capacidade de dominar, integrar e mobilizar seus saberes como condição para sua prática (educativa).

Outro posicionamento extremamente pertinente, trazido por Tardif (2002), é a contraposição em relação à ideia tradicional da relação entre teoria e prática. Compartilhamos do pensamento do autor no que concerne o saber ser produzido conjuntamente à prática. Isso significa que a relação existente acontece de forma concomitante, explorando e construindo de maneira igualitária a "teoria praticada". A partir deste pensamento, defendemos o êxito de nossa abordagem, a qual se apresentou valorizando teoria e prática de forma equilibrada e concomitante (práxis) durante todo o processo de intervenção junto aos professores pesquisados à época, conforme pesquisas realizadas por Antério e Gomes-da-Silva (2012; 2013).

Tal questão conclama outra que fora de extrema importância na pesquisa, a de transformar o já existente em algo diferente, ou até mesmo novo. Ancoramo-nos em Morin (1997), compreendendo a necessidade de mudar, de criar novas alternativas e desenvolver critérios e procedimentos éticos diversificados. Sendo assim, é fundamental resistir e manter viva a esperança de transformação num mundo cada vez mais excludente e competitivo. Esta reflexão nos remete a outras duas ideias, igualmente importantes e necessárias para a compreensão da complexidade da formação humana. Trata-se do ser humano não limitar-se tão somente ao aspecto biológico ou apenas cultural. Segundo Morin (1991, p. 78), "há algo mais do que a singularidade ou que a diferença de indivíduo para indivíduo. É o fato que cada indivíduo é um sujeito". A partir dessa afirmativa, temos o ensejo que propicia a prática crítica e reflexiva de nossos próprios saberes, nossas próprias atitudes frente ao desafio de ensinar.

Por fim, enaltecemos outros ensinamentos, desta vez por Freire (1999), quanto ao reconhecer-se inacabado, possível de ser completado pelo novo, pelo vir a ser. A educação deve realizar-se como prática da liberdade, numa pedagogia em que o oprimido tenha condições de descobrir-se e conquistar-se como sujeito de sua própria destinação histórica. $\mathrm{Na}$ esteira dessa concepção freiriana (1999), elucidamos alguns pontos que consideramos essenciais para uma prática educativa libertadora. Primeiro, não é possível educar para liberdade se não se entende parte viva do mundo em que vive. Não se aprende a palavra isoladamente, mas em sua comunicação com o mundo. Estudar é interagir com o mundo, compreender-se responsável por sua constituição. Isso implica no aspecto contrário à 
ANTÉRIO, D; SILVA, P. N. G.

comunicação, na perspectiva da cultura de massa, a qual, por muitas vezes, desconsidera a qualidade do processo como um todo, seus princípios e aspectos fundantes do ser social, como a própria cultura.

A pedagogia defendida por Freire $(1999 ; 2003)$ propõe um ensino por meio do diálogo, da liberdade, do exercício coletivo, participativo e transformador. A partir desse raciocínio, oferecemos nessa pesquisa, dantes mencionada (ANTÉRIO; GOMES-DA-SILVA, 2012; 2013), uma vivência que provocasse o educador a refletir sobre seu corpo comunicativo e a implicação deste na prática educativa libertadora, porque consciente dos processos de interação vividos. Oferecemos uma ação interventiva que desencadeasse ressonâncias pedagógicas, auxiliando o professor no cotidiano de sua prática docente.

\section{CONSIDERAÇÕES FINAIS}

Sendo assim, entendemos a educação como prática social e o saber docente de experiência como mediação, permeada pela CC, visto que os sujeitos da educação, conjuntamente ao espaço/território escolar, comunicam-se continuamente, recorrendo a linguagem não-verbal. Desse modo, a noção de corpo comunicativo se faz extremamente significativa para o processo educacional, ao compreender que são os processos comunicativos que comprometem a aprendizagem, porque comprometem as interações entre os sujeitos da educação, em termos do tratamento dos conhecimentos, habilidades e valores.

Portanto, posicionamo-nos a favor de uma relação dinâmica e equilibrada entre o que temos de mais consolidado no campo dos saberes docentes na educação e o conhecimento acumulado sobre a teoria da comunicação, em especial, da CC, possibilitando uma articulação ampla entre as áreas da Educação, Arte e Educação Física, de forma diversificada, integrada, e não hierárquica. Entendemos tais áreas como práticas sociais que possibilitam um agir pedagógico mais consciente sobre si mesmo, tanto para quem educa quanto para quem é educado. Mais que isso, um agir consciente na direção do processo de transformação social, ou seja, que colabore com os interesses dos menos favorecidos, da classe trabalhadora, opondo-se aos poderes da opressão.

Como vimos, corpo comunicativo é mais que uma técnica de gestão de classe. Referese a um saber docente capaz de auxiliar o professor na tomada de consciência das suas 
comunicações, dos diálogos estabelecidos em cada espaço que ocupa, em cada roupa que veste e em cada movimento realizado durante a aula. Esse saber implica o docente a estar atento para toda "zona de corporeidade" criada pela circunstância de aprendizagem. O espaço físico da aula, as relações entre os alunos, as trocas de olhares e toques são entendidos como fluxo de informação gerando ambiências educativas.

Portanto, nada foge da comunicação, desde a edificação e funcionamento da gestão até os simples gestos dos educandos, são todos comunicações que devem estar sendo consideradas pelo professor. A CC é um constituinte da construção teórica da Pedagogia da Corporeidade, cujos fundamentos abrangem o sentir, o agir e o refletir, como partícipe de toda situação de movimento. De modo que CC constitui-se campo científico e espaço de intervenção pedagógica que envolve o processo de assimilação sensorial, interação biopsicossocial, e significação cultural.

\title{
THE BODY COMMUNICATION AS KNOW LEARN EDUCATIONAL
}

\begin{abstract}
This article discusses the Body Communication as a teacher knowledge. Noting the reduced body design of the teaching-learning process and the inclusion of this subject in the role of teaching knowledge, this study elucidates the possibilities of a pedagogical act more aware of their own body in the educational activity. Assumes that the level of consciousness of the teacher happens when he realizes that his gestures, clothing and occupations in the spaces of the classroom, are as eloquent as the information transmitted on a given subject. It is argued, therefore, that the conscious body language can be helpful to know in the educational practice of teachers teaching.
\end{abstract}

Keywords: Education, Know, Communication, Body

\section{LA COMUNICACIÓN CORPORAL COMO SABER LOS PROFESORES}

\section{Resumen}


ANTÉRIO, D; SILVA, P. N. G.

En este artículo analiza la Comunicación del Cuerpo en conocimiento de los profesores. Tomando nota del diseño de la carrocería reducida del proceso de enseñanza-aprendizaje y la inclusión de este tema en el papel del conocimiento docente, este estudio aclara las posibilidades de un acto pedagógico más conciencia de su propio cuerpo en la actividad educativa. Se asume que el nivel de la conciencia del maestro ocurre cuando se da cuenta de que su gestos, vestimenta y ocupaciones en los espacios de la sala de clase, son tan elocuentes como la información transmitida sobre un tema determinado. Se argumenta, por lo tanto, que el lenguaje corporal consciente puede ser útil saber en la práctica educativa de los profesores que enseñan.

Palabras-clave: Educación; Saber; Comunicación; Cuerpo

\section{REFERÊNCIAS}

ANGHEBEN, Vera Lucia Zamberlan. A ginástica rítmica na corporeidade dos acadêmicos de educação física: relações entre o pensar, o falar e agir com o corpo. Dissertação de mestrado, Universidade Federal do Rio Grande do Sul, Porto Alegre, 2005. Disponível em: http://migre.me/eFJuy Acesso em: 22 mai. 2012.

ANTÉRIO, Djavan; GOMES-DA-SILVA, Pierre Normando. Corpo comunicativo: analisando a comunicação corporal por meio da exploração espacial do educador. Motrivivência (Florianópolis), v. 41, p. 206-222, 2013.

Corpo Comunicativo: analisando a comunicação corporal por meio da gestualidade do educador. Vivência (UFRN), v. 1, p. 183-198, 2012.

- Corpo Subjetivado: conceitos e significados para a educação. Caderno de Educação Física (UNIOESTE. Impresso), v. 10, p. 67-73, 2011.

DELEUZE; G.s; GUATARI, F. O anti-Édipo: capitalismo e esquizofrenia. Lisboa: Assírio \& Alvim, 1995.

ARGYLE, Michael. Bodily communication. New York: Methuen \& Co. 2nd, 1988.

BACRI, Ana Paula Romero. Influência dos bloqueios corporais na educação. Dissertação de mestrado, Universidade Federal de Uberlândia, Uberlândia, MG, 2005. Disponível em: http://migre.me/eFJPw Acesso em: 18 out. 2012.

CORRAZE, Jacques. As comunicações não-verbais. RJ: Zahar, 1982. 
COSTA, Sandra Barbosa; GOMES-DA-SILVA, Pierre Normando; SCHULZE, Guilherme. A linguagem expressiva do andar humano. In: CATTUZZO, Maria Tereza; CAMINHA, Iraquitan de Oliveira (Orgs.). Fazer e pensar ciência em educação física - livro 1. JP: Ed. Universitária UFPB, 2012, p. 219-238.

COZZI, Tânia de Rezende. Na passarela de uma escola: a evolução da linguagem escrita ao ritmo da fala e do corpo. Dissertação de mestrado, Universidade Federal Fluminense, Niterói, RJ, 2004. Disponível em: http://migre.me/eFK2N. Acesso em: 26 fev. 2013.

DAVIS, Flora. A comunicação não-verbal. São Paulo, Summus, 1979.

FARAH, Marisa Helena Silva. O corpo na escola: mapeamentos necessários. Paidéia (USP. Ribeirão Preto. Impresso), v. 20, p. 401-410, 2010.

Corpo-identidade: leituras, práticas e vivências na formação de professores em diferentes licenciaturas. Tese de doutorado, Universidade de São Paulo, São Paulo, 2011. Disponível em: http://migre.me/eFKCG. Acesso em 11 març. 2013.

FERNANDES, Tânia da Costa. Educação sensibilidade: A ética e a estética da corporeidade no currículo. Tese de doutorado não publicada, Universidade de São Paulo, São Paulo, 2004.

FOUCAULT, Michel. Vigiar e punir. 7. ed. Petrópolis/RJ: Vozes, 1987.

FREIRE, João Batista. Educação de corpo inteiro: teoria e prática da Educação Física. São Paulo: Scipione, 2009.

FREIRE, Paulo. A Educação como Prática da liberdade. Rio de Janeiro: Paz e Terra, 1999. . Pedagogia da autonomia. Rio de Janeiro: Paz e Terra, 1999. Pedagogia do oprimido. São Paulo: Paz e Terra, 2003.

GAIA, Adroaldo. A reinvenção dos corpos: por uma pedagogia da complexidade. Sociologias. V. 15, p.250-272, 2006. Disponível em: http://migre.me/eFKYi Acesso em: 20 març. 2013.

GADOTTI, Moacir. Pedagogia da práxis. 2. ed., São Paulo: Cortez, 1998.

GALVÃO, Edna Ferreira Coelho. A produção da corporalidade na escola: uma análise do projeto da Educação de jovens e adultos em Angra dos Reis. Tese de doutorado, Universidade Federal Fluminense, Niterói, RJ, 2004. Disponível em: http://migre.me/eFLUc. Acesso em 20 març. 2013.

GLUSBERG, Jorge. A arte da performance. São Paulo: Perspectiva, 2003.

GOMES-DA-SILVA, Pierre Normando. O jogo da cultura e a cultura do jogo: por uma semiótica da corporeidade. João Pessoa: Ed. Universitária UFPB, 2011. 
Prática de ensino em educação física: por uma formação do professor-pesquisador. In: HERMIDA, Jorge Fernando (Org.). Educação física: conhecimento e saber escolar. João Pessoa: Ed. Universitária UFPB, 2009.

JAKOBSON, Roman. Linguística e comunicação. SP: Cultrix, 1999.

KNAPP, Mark L.; HALL, Judith A. Comunicação não-verbal na interação humana. Tradução de Mary Amazonas Leite Barros. São Paulo: JSN, 1999.

MACHADO, Irene; ROMANI, V. Semiótica da comunicação: da semiótica da natureza à cultura. Revista FAMECOS, Porto Alegre, v.17, n.2, p.87-97, maio/agosto, 2010.

MEDINA, João Paulo Subirá. A Educação Física cuida do corpo... e "mente". 15. ed. Campinas: Papirus, 2001.

. O brasileiro e seu corpo. 8. ed. Campinas: Papirus, 2002.

MERLEAU-PONTY, Maurice. Fenomenologia da percepção. Tradução de Carlos Alberto Ribeiro de Moura. São Paulo: Martins Fontes, 1999.

MILLER, Jussara. O corpo presente: uma experiência sobre dança-educação. Educação Temática Digital. Campinas, SP v.16 n.1, 2014. Disponível em: http://goo.gl/PEyQwW Acesso em: 08 mai. 2014.

MORIN, Edgar. Amor, poesia e sabedoria. RJ: Bertrand Brasil, 1997. Introdução ao pensamento complexo. Lisboa: Instituto Piaget, 1991.

Unesco, 2000.

Os sete saberes necessários à educação do futuro. São Paulo: Cortez; Brasília:

PEASE Allan; PEASE Bárbara. Desvendando os segredos da linguagem corporal. Rio de Janeiro: Sextante, 2005.

PEDERIVA, Patrícia Lima Martins. $O$ corpo no processo ensino-aprendizagem de instrumentos musicais: percepção de professores. Dissertação de mestrado não publicada, Universidade Católica de Brasília, Brasília, 2005. Disponível em: http://migre.me/eFMcx Acesso em: 15 abr. 2013.

PIAGET, Jean. O desenvolvimento do pensamento: equilibração das estruturas cognitivas. Lisboa: Dom Quixote, 1977.

. A formação do símbolo na criança: imitação, jogo e sonho, imitação e representação. Rio de Janeiro: LTC, 1990.

PICARD, Dominique. Del código al deseo: el cuerpo em la relación social. Buenos Aires: Paidos, SACIF, 1986. 
RECTOR, Mônica; TRINTA, Aluízio Ramos. A comunicação não-verbal: a gestualidade brasileira. Petrópolis: Vozes, 1985.

Comunicação do corpo. São Paulo : Ática, 1999.

SACRISTÁn, José Gimeno. Poderes instáveis em Educação. Trad. de Beatriz Affonso Neves. Porto Alegre: Artes Médicas, 1999.

O aluno como invenção. Porto Alegre: Artmed, 2005.

TARDIF, Maurice. Saberes docentes e formação profissional. Petrópolis: Vozes, 6. ed. 2006.

VIEIRA, Josimar de Aparecido. A qualidade do processo de formação inicial de professores: reflexões sobre o que está sendo pesquisado. Revista Reflexão e Ação, Santa Cruz do Sul:UNISC, v.17, n2, p.125-140, jul./dez. 2009. Disponível em: http://goo.gl/o5Tc8y Acesso em: 04 ago. 2013.

VOGT, Grasiela Zimmer; MOROSINI, Marília Costa. Formação continuada de professores e reunião pedagógica: construindo um estado de conhecimento. Revista Reflexão e Ação, Santa Cruz do Sul:UNISC, v.20, n1, p.24-37, jan./jun. 2012. Disponível em: http://goo.gl/HVZCo6 Acesso em: 04 ago. 2013.

VYGOTSKY, Lev. Pensamento e Linguagem. São Paulo: Martins Fontes, 1989.

WEIL, Pierre; TOMPAKOW, Roland. O corpo fala: a linguagem silenciosa da comunicação não-verbal. Rio de Janeiro: Vozes, 1986.

Data de recebimento: 29/08/2012

Data de aceite: 05/05/2014 